\title{
Protective Role of Urtica Dioica on Testicular Torsion/Detorsion-Induced Ischemia- Reperfusion Injury in Rats
}

\author{
Hakan Akdere
}

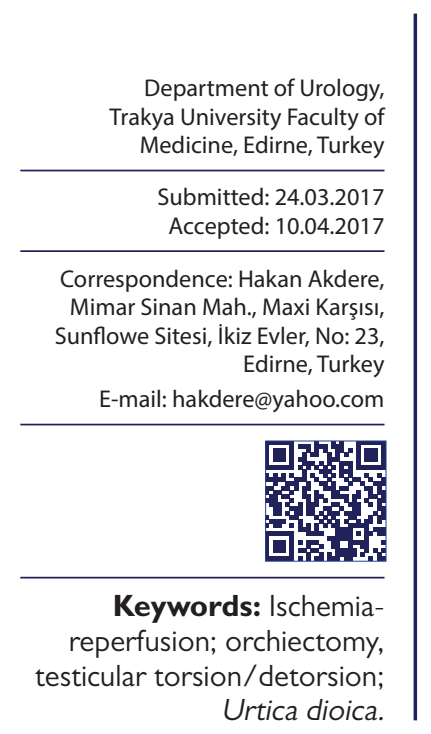

Urtica dioica.

\begin{abstract}
Objective: The aim of this study was to investigate the protective effect of Urtica dioica (UD) on testicular torsion/detorsion-induced ischemia-reperfusion (I/R) injury.

Methods: Total of 32 male Wistar albino rats were divided into 4 groups ( 8 animals per group) as follows: Group I, sham-operated control group; Group 2, I/R group; Group 3, UD (250 mg/kg for I4 days) group; and Group 4, I/R+UD (250 mg/kg for I4 days) group. Testicular torsion was created by rotating the right testis $720^{\circ}$ clockwise. Ischemia period was 5 hours and orchidectomy was performed after 5 hours of detorsion.
\end{abstract}

Results: Biochemical analyses of testicular tissue revealed malondialdehyde level was significantly higher in I/R group compared with that of control group and UD group $(p<0.0 \mathrm{I})$. Significant increase was also observed in I/R+UD group when compared with control group and UD group $(p<0.05)$. Testis tissue glutathione level was not significantly different between groups $(p>0.05)$. Additionally, UD-treated animals had better histopathological findings compared with I/R group.

Conclusion: There are very few studies of histopathological changes in UD treatment of testicular torsion/detorsion-induced I/R injury in rats. UD may be a promising approach for treatment of testicular torsion.

\section{INTRODUCTION}

Testicular torsion is a urological emergency caused by torsion of the spermatic chord, and generally surgical intervention is needed to re-establish blood flow. ${ }^{[1]}$ Ischemia lasting more than 6 hours can cause irreversible testicular injury. Surgical detorsion allows realization of reperfusion, and it is currently the only treatment alternative. Despite successful corrective surgery, testicular oxidative stress as result of ischemia-reperfusion (I/R) injury can lead to germ cell apoptosis, and loss of spermatogenesis. ${ }^{[2]}$ Definition of antioxidants, free radical scavengers, and pharmacological agents that could be used in treatment as adjunct to surgical repair to spare testis from I/R injury are important clinical objectives.

Urtica dioica (UD) is an herbal plant which contains essential amino acids, vitamins, and various nutrients. ${ }^{[3]}$ UD has been used by people to promote urine output, adjust activity cycle, balance adrenal tonus and glandular functions, and for its anti-inflammatory action. ${ }^{[4]}$ One of the most important components of UD root is flavonoids, which have antioxidant effects and which can modify some specific enzymes with resultant inactivation of agents such as nitrite peroxide and hydroxide radicals. ${ }^{[5]}$

Antiproliferative, anti-inflammatory, antioxidant, and antiviral properties of UD (also known as stinging nettle) have been demonstrated in many studies. ${ }^{[6,7]}$ Protective effect against renal I/R injury and hepatic damage related to biliary tract obstruction have been also reported. ${ }^{[8,9]}$ As far as we know, the impact of UD on testicular I/R injury has been investigated in only a very few studies. The present study was conducted with the aim of examining potential protective effect of UD on torsion/detorsion-induced testicular I/R injury. 


\section{MATERIAL AND METHODS}

\section{Animals and reactants}

The protocol of this experiment was approved by the ethics committee of Trakya University Faculty of Medicine. This study used 32 healthy, 16-week-old, male Wistar albino rats each weighing 275 to $325 \mathrm{~g}$ obtained from the Trakya University Animal Care and Research Unit. Access to food and tap water was allowed ad libitum. The rats were housed in cages, at mean temperature of $21 \pm 10^{\circ} \mathrm{C}$, and 12 -hour light and dark cycles. Ambient humidity was $55 \%$ to $60 \%$. Care of animals was provided in compliance with the guidelines for the care and use of laboratory animals published by the National Academy of Sciences. Anesthesia was achieved with injection of xylazine (10 mg/ $\mathrm{kg})$ and ketamine $(90 \mathrm{mg} / \mathrm{kg})$ combination administered through intraperitoneal (IP) route.

\section{Experimental groups}

I. Control group $(n=8)$ : Rats were pretreated with $0.9 \%$ sodium chloride $(\mathrm{NaCl})$ delivered through feeding tube for 14 days before sham operation.

2. I/R group $(n=8)$ : Rats were pretreated with $0.9 \% \mathrm{NaCl}$ delivered through feeding tube for 14 days before application of 5 hours of testicular ischemia and 5 hours of reperfusion.

3. UD group $(\mathrm{n}=8)$ : Rats were pretreated with $250 \mathrm{mg} / \mathrm{kg}$ UD delivered through feeding tube for 14 days before operation.

4. $/ / R+\cup D$ group $(n=8)$ : Rats were pretreated with 250 $\mathrm{mg} / \mathrm{kg}$ UD delivered through feeding tube for 14 days before application of 5 hours of ischemia followed by 5 hours of reperfusion.

\section{Surgical procedures}

All surgical procedures were performed under sterile conditions and xylazine/ketamine (10/90 mg/kg, IP) anesthesia. Scrotum was accessed through midline incision. Tunica vaginalis was opened, and left testis was exposed. Left testis was rotated $720^{\circ}$ clockwise, fixed to the scrotum, and kept in torsion position with $4-0$ silk sutures. ${ }^{[0]}$ Ischemia was maintained for period of 5 hours, and after 5 hours of detorsion, orchidectomy was performed. Left orchidectomy was performed in all groups. Tissue specimens were obtained from testicle for histopathological examination.

\section{Histopathological evaluation}

All rats were orchidectomized and testes were cut longitudinally. Testicular tissue samples were subjected to routine histological procedures and embedded in paraffin blocks. All testicles $(n=32)$ were equally divided into 2 groups. The first group $(n=16)$ was preserved to determine malondial- dehyde (MDA) and glutathione (GSH) expressions. The other half of testicular specimens $(n=16)$ was preserved with Bouin solution. Five $\mu \mathrm{m}$-thick sections were obtained and stained with hematoxylin-eosin. Three slides were prepared with specimens retrieved from upper, lower, and middle parts of testes. Testicular tissue samples were examined and evaluated under standard light microscope by a pathologist blinded to the study.

\section{Measurement of seminiferous tubule diameter}

In each section, diameter of 10 separate, randomly chosen, seminiferous tubuli were measured under IOX magnification. Measurement of seminiferous tubule diameter (STD) was expressed in $\mu \mathrm{m} .{ }^{[8]}$

\section{Evaluation of the spermatogenesis \\ (mean testicular biopsy score)}

Spermatogenesis was evaluated histopathologically using Johnsen mean testicular biopsy score (MTBS) criteria.

I: There are no seminiferous tubuli, and tubular sclerosis is present.

2: Presence of Sertoli cells only is observed, without germinal epithelial cells.

3: Spermatogonia only are present.

4: There are few spermatocytes, and arrest of spermatogenesis at primary spermatocyte stage.

5: There are many spermatocytes, but spermatids are not detected.

6: There are very few early spermatids with spermatogenetic arrest at spermatid stage, and impaired differentiation into spermatids.

7: There are many early spermatids without late spermatids.

8: There are a few late spermatids.

9: There are many late spermatids and irregular tubular epithelium.

10: There is full spermatogenesis. ${ }^{[12]}$

The sections were evaluated under bright-field microscopy (Olympus BX50; Olympus Corp., Tokyo, Japan). ${ }^{[8]}$

\section{Evaluation of histopathological injury} of seminiferous tubuli

A 4-level grading scale similar to that described by Cosentino et al. was used. ${ }^{[13]}$ Grade I: Normal testicular architecture with regularly organized germinal cells; Grade 2: Loss of cohesion among regular germinal cells and closely packed seminiferous tubuli; Grade 3: Shrunken picnotic cells and irregular, dispersed, less distinct germinal cells adjacent to seminiferous tubuli; Grade 4: Closely packed seminiferous tubuli filled with germinal cells destroyed by coagulation necrosis. ${ }^{[13]}$ 


\section{Malondialdehyde and glutathione testing}

Testicular tissue samples were homogenized in $150 \mathrm{mM}$ extremely cold potassium chloride solution for determination of MDA level. Homogenates were centrifuged at $2600 \mathrm{~g}$ for 10 minutes at $4^{\circ} \mathrm{C}$. MDA is an indicator of lipid peroxidation. It is found in testicular tissue. MDA concentration was measured based on reaction with thiobarbituric acid. MDA was quantified using extinction coefficient of $1.56 \times 105 \mathrm{M}^{-1} \mathrm{~cm}^{-1}$, and expressed as nmol/mg. ${ }^{[14]} \mathrm{GSH}$ level in testicular tissue was determined using Ellman method. ${ }^{[15]}$ Results were expressed as $\mu \mathrm{mol} / \mathrm{g}$.

\section{Statistical analysis}

All data were presented as mean $\pm S D$. Differences in measured parameters between 3 groups were analyzed using non-parametric Kruskal-Wallis test. Pairwise comparisons between groups displaying significant values were evaluated using Mann-Whitney $U$ test. $P$ value $<0.05$ was considered statistically significant.

\section{RESULTS}

\section{Biochemical analysis}

Testicular MDA and GSH values of all groups are presented in Table I. MDA level was significantly different between groups $(p<0.05)$. Testicular tissue MDA level was significantly higher in I/R group compared with control and UD groups $(p<0.01)$. MDA level in $I / R+U D$ group was significantly lower than that of $I / R$ group $(p<0.05)$. Compa- rison of testicular GSH level between groups did not yield significant results $(p>0.05)$.

\section{Histopathological evaluation}

In control and UD groups, normal testicular architecture was observed. Morphology of seminiferous tubuli was within normal limits and spermatogenesis was preserved. Primary and secondary spermatocytes, spermatids, and spermatozoa were seen (Figures la-d). Following I/R, diameter of seminiferous tubuli decreased significantly. In addition to tubular distortion, dispersion, degeneration, loss of maturation, interstitial edema, and bleeding were observed (Figures 2a, b). Animals treated with UD demonstrated better histopathological findings compared with I/R group (Figures 2c, d). In UD group, tubular morphology was preserved and there was spermatogenic maturation to stage of spermatozoa formation. This group also had greatest number of seminiferous tubuli. Treatment with UD preserved intact morphology of seminiferous tubuli and testicular function.

Mean seminiferous tubule diameter (MSTD), Johnsen MTBS value, and histopathological injury grade of each group are presented in Table 2. In control and UD groups, MSTD and Johnsen MTBS scores were significantly higher than I/R group $(p<0.0 I)$. Control and UD groups also had significantly lower histopathological grade compared with I/R group $(p<0.0 I)$. In I/R+UD group, MSTD and Johnsen MTBS scores were significantly lower than those of control and UD groups $(p<0.0 I)$. Histopathological grade in I/R group was significantly higher when compared with that of

Table I. MDA and GSH levels of groups

\begin{tabular}{|c|c|c|c|c|}
\hline & Control Group $(n=8)$ & I/R Group $(n=8)$ & UD Group $(n=8)$ & I/R + UD Group $(n=8)$ \\
\hline & Mean $\pm S D$ & Mean $\pm S D$ & Mean $\pm S D$ & Mean $\pm S D$ \\
\hline $\mathrm{MDA}^{*}$ & $0.19 \pm 0.09$ & $0.44 \pm 0.06^{\mathrm{a}}$ & $0.09 \pm 0.03$ & $0.34 \pm 0.04^{b}$ \\
\hline $\mathrm{GSH}^{* *}$ & $4.23 \pm 0.51$ & $4.14 \pm 1.09$ & $4.02 \pm 0.21$ & $4.45 \pm 0.34$ \\
\hline
\end{tabular}

I/R: Ischemia/reperfusion; GSH: Glutathione; MDA: Malondialdehyde; UD: Urtica dioica; SD: Standard deviation.

${ }^{*}$ Concentrations are expressed as nmol/gram tissue. ${ }^{* *}$ Concentrations are expressed as $\mu \mathrm{mol} / \mathrm{gram}$ tissue.

${ }^{\mathrm{a}} \mathrm{p}<0.01$ compared to Control and UD group. ${ }^{\mathrm{b}} \mathrm{P}<0.05$ compared to Control and UD+I/R group.

Table 2. MSTD, Johnsen MTBS, and histopathological injury grade of groups

\begin{tabular}{|c|c|c|c|c|}
\hline & Control group $(n=8)$ & I/R Group $(n=8)$ & UD Group $(n=8)$ & I/R + UD Group $(n=8)$ \\
\hline & Mean \pm SD & Mean $\pm S D$ & Mean $\pm S D$ & Mean $\pm S D$ \\
\hline $\operatorname{MSTD}(\mu \mathrm{m})$ & $267 \pm 4.1$ & $194.6 \pm 5.1^{\mathrm{a}}$ & $265.8 \pm 7.4$ & $233.5 \pm 8.4^{\mathrm{b}}$ \\
\hline MTBS & $9.6 \pm 0.5$ & $3.1 \pm 0.7^{a}$ & $9.3 \pm 0.5$ & $4.5 \pm 0.5^{b}$ \\
\hline Grade & $1.2 \pm 0.4$ & $4.5 \pm 0.5^{\mathrm{a}}$ & $1.16 \pm 0.7$ & $3.0 \pm 0.6^{\mathrm{b}}$ \\
\hline
\end{tabular}

I/R: Ischemia/reperfusion; MSTD: Mean seminiferous tubule diameter; MTBS: Mean testicular biopsy score; UD: Urtica dioica; SD: Standard deviation. ${ }^{a} p<0.01$ compared to control and UD group. ${ }^{b} p<0.01$ compared to control and UD+1/R group. 

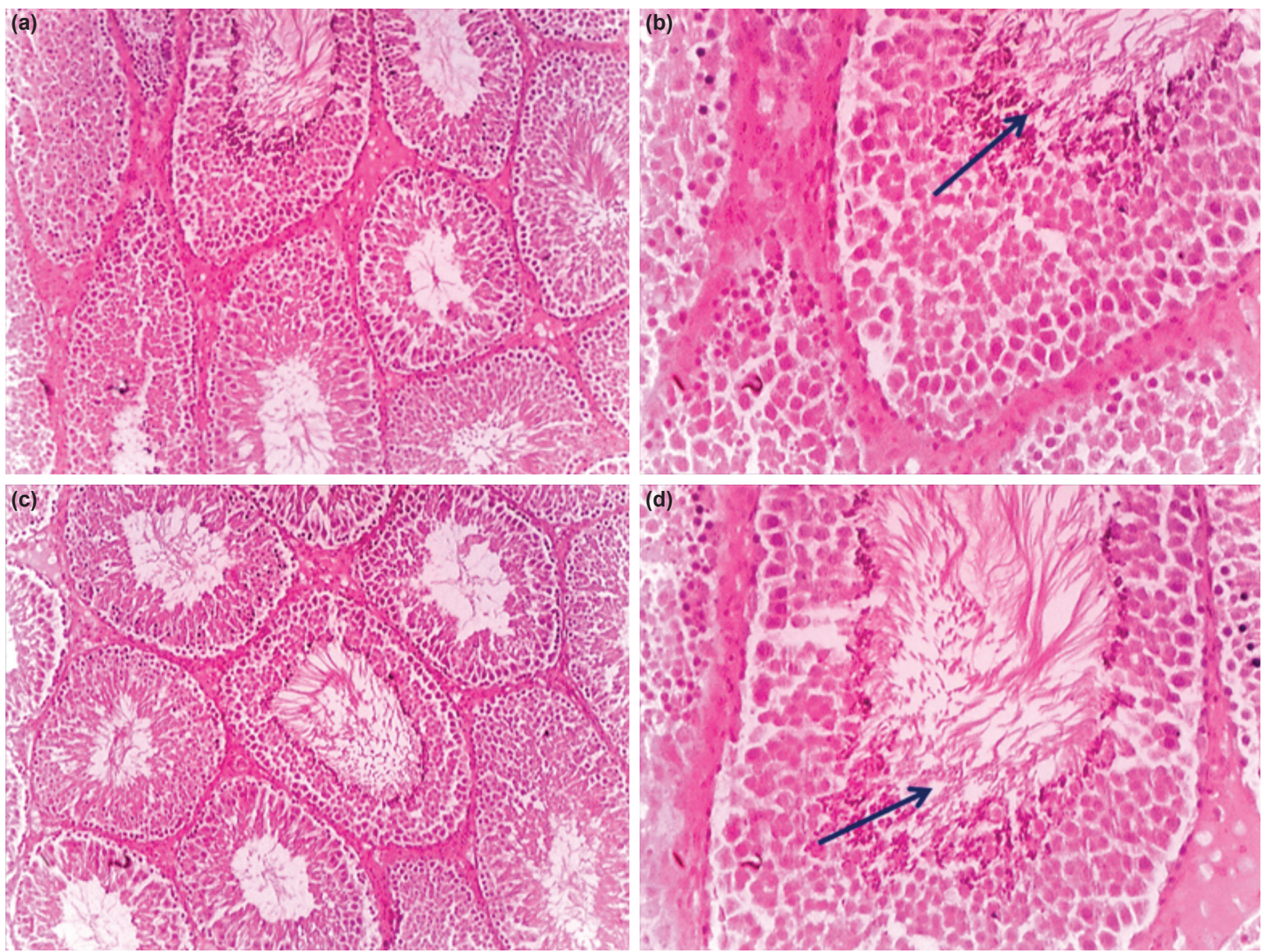

Figure 1. (a-d) In the Control and UD groups, testes showed normal testicular architecture. Seminifer tubular morphology was normal and spermatogenesis was continued. Arrows show primary-secondary spermatocytes, spermatids and spermatozoas (Control group, HE, 1A:X100, 1B:X400; Urtica Dioica (UD) Group HE, 1C:X100,1D:X400).

control and UD groups $(\mathrm{p}<0.0 \mathrm{I})$. In addition, significant increase was observed in MSTD and Johnsen MTBS scores in $I / R+U D$ group relative to $I / R$ group $(p<0.0 I)$. Interestingly, following treatment with UD, histopathological grade in $I / R+U D$ group was significantly lower compared with I/R group $(p<0.01)$.

\section{DISCUSSION}

Testicular torsion results in impairment of continuity of perfusion in the affected testis. Following reperfusion, production of free oxygen radicals increases the severity of testicular injury. ${ }^{[14]}$ Inconsistent and controversial outcomes have been reported in the literature about status of the contralateral testis, and destructive changes have been also been indicated in the contralateral testis. ${ }^{\left[{ }^{[5-17]}\right.}$ These changes have been explained by autoimmunization mechanism acting against spermatogonia. This process stems from disruption of blood-sperm barrier, decrease in blood flow due to reflexive sympathetic response, and excessive production of reactive oxygen species following reperfusion. ${ }^{[8-20]}$
Results of this study reveal that pretreatment with UD had favorable protective effect on biochemical and histopathological alterations in testes of rats as result of $\mathrm{I} / \mathrm{R}$-induced testicular injury.

\section{Essential findings}

I) Following I/R, there was marked increase in testicular tissue MDA concentration; 2) UD demonstrated protective effects on testicular tissue, with decreased MDA level after I/R; 3) Prominent histopathological changes were as follows: decrease in diameter of seminiferous tubuli, tubular impairment, disorganization, loss of maturation, interstitial edema, and decreased bleeding; 4) Protective effects of UD on testicular tissue were determined by MSTD, Johnsen MTBS score, and grading. This study represents a new contribution to the literature, as we used higher dose of UD as antioxidant compared with literature data, and observed markedly apparent protective effects.

Sayhan et al. investigated potential therapeutic effects of UD on renal I/R injury in mice. ${ }^{[8]}$ Histopathological architecture of kidneys of mice in $I / R+U D$ group was much bet- 

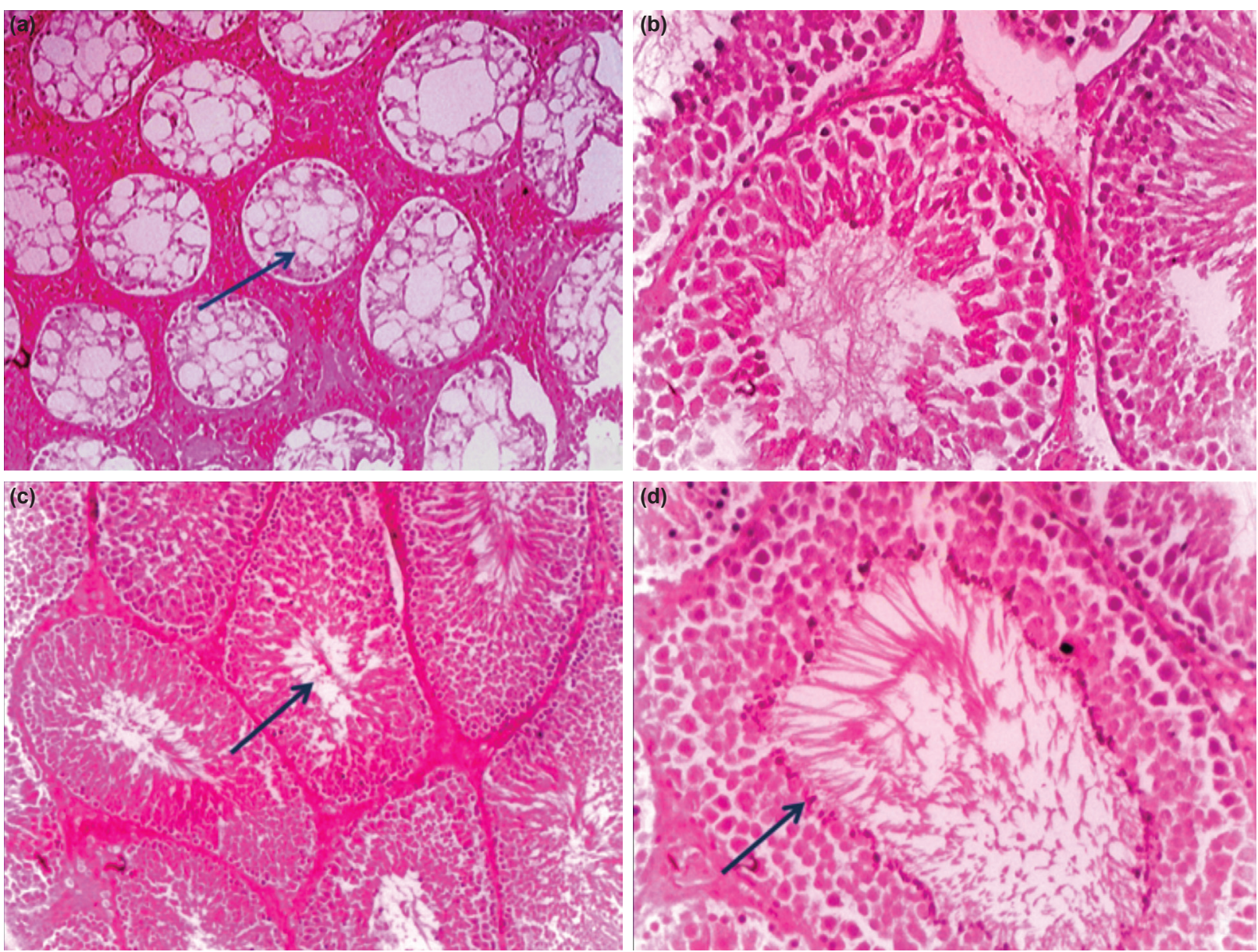

Figure 2. (a-d) Ischeamia reperfusion (I/R) group marked decrease in the seminiferous tubular diameter (STD). Additionally tubular distortion, disorganization, degeneration, loss of maturation, interstitial edema and hemorrhage were observed. Arrow shows necrotic seminifer tubules (HE, 2A:X100, 2B:X400). Urtica Dioica (UD) group showed an improved histopathologic findings compared with I/R group. Arrows show UD preserved seminiferous tubular morphology (HE, 2C:X100, 2D:X400).

ter than that of those in I/R group. Results they obtained revealed that treatment with UD protected against renal injury. Kidneys demonstrated normal glomeruli and mild degree of mononuclear cell infiltration. In addition, authors demonstrated that UD inhibited apoptotic cell death in proximal and distal tubuli cells using terminal deoxynucleotidyl transferase (TdT) dUTP nick-end labeling (TUNEL) method. Tissue sections retrieved from renal cortex demonstrated marked increase in number of TUNEL-positive cells in I/R group mice. Treatment with UD prominently decreased reactivity and number of TUNEL-positive cells. The authors emphasized that results they obtained strongly indicated potential clinical benefits of UD in patients undergoing renal transplantation or partial nephrectomy.

Oğuz et al. evaluated protective effects of UD on hepatic injury in rats with ligated biliary tract. ${ }^{[9]}$ Application of UD reduced changes in liver histology following biliary duct ligation (BDL). Treatment with UD decreased cytokeratinpositive ductular proliferation, smooth muscle actin, and TUNEL activity. Treatment with UD led to less choledotic liver injury, biliary ductular proliferation, and BDL-induced fibrosis. ${ }^{[9]}$ In another study performed by the same authors, positive effects of UD on hepatic regeneration after partial hepatectomy in mice were investigated. Histopathological analysis revealed treatment with UD conspicuously increased mitotic index and proliferation index, but significantly lowered apoptotic index. In addition, as was demonstrated in our study, UD treatment significantly decreased level of tissue MDA. Oğuz et al. also noted that pretreatment with UD was beneficial for post-partial hepatectomy hepatic regeneration in mice. ${ }^{[2]]}$

Ghafari et al. conducted histopathological and morphometrical study to determine effects of UD on testes of mice with diabetes induced by streptozotocin (STZ). ${ }^{[22]}$ They underlined that external MSTD and height of seminiferous tubuli significantly decreased in diabetic mice. They reported that hydroalcoholic extract of UD leaves had no effect on changes in seminiferous tubuli after induction of diabetes with STZ. ${ }^{[22]}$ Golalipour et al. investigated protective effects of UD on morphometrical and morpholo- 
gical changes in seminiferous tubuli among STZ-induced diabetic mice. ${ }^{[23]}$ External seminiferous tubular diameter and seminiferous epithelial height were significantly lower in diabetic group compared with controls, and these parameters were greater in the treated group when compared with diabetic group. ${ }^{[23]}$

Kanter et al. investigated protective effects of UD and nigella sativa (NS) on antioxidant enzyme systems, lipid peroxidation, and liver enzymes in mice treated with carbon tetrachloride (CCl4). ${ }^{[2]}$ They concluded that treatment with UD or NS (singly or in combination) significantly lowered MDA and liver enzymes, and improved antioxidant level in mice treated with $\mathrm{CCl}^{\left[{ }^{[2]} \mathrm{Cai}\right.}$ et al. investigated therapeutic effects of Serenoa repens, UD, quercitin and curcumin extracts associated with prulifloxacin in chronic bacterial prostatitis (CBP). Patients with National Health Institute class II prostatitis were included in the study. In Group A, total of 106 patients were treated with prulifloxacin and in Group B, 37 patients received only antibiotherapy. Clinical and microbiological effectiveness of treatment were tested at $I$ and 6 months. One month after treatment, $89.6 \%$ of Group A patients did not report any CRP-related symptoms. However in Group B, disease did not recur in only $27 \%$ of patients. This intergroup difference in symptoms and quality of life was found to be significant. Six months after treatment, Group A remained disease-free, while 2 patients in Group B had recurrence of CBP. Extracts used in Group A increased clinical effectiveness of prulifloxacin among CBP patients. ${ }^{[25]}$

Safarinejad et al. examined effects of UD in treatment of benign prostatic hyperplasia (BPH) and symptomatic improvement of lower urinary tract symptoms (LUTS). ${ }^{[26]}$ Following treatment with UD, peak flow rate, International Prostate Symptom Score, and maximum urinary flow rate improved, and post-void residual urine decreased. Lopatkin et al. performed a double-blind, placebo-controlled, multicenter study to investigate reliability and effectiveness of combined use of UD and Sabal extract in LUTS. ${ }^{[2]]}$ They reported that treatment with UD and Sabal extract provided important clinical benefits for at least 96 weeks. In addition, combination of these extracts demonstrated excellent tolerability during long-term application. ${ }^{[27]}$

In a double-blind, placebo-controlled study, Melo et al. evaluated effectiveness of UD and Pygeum Africanum extract in treatment of BPH. ${ }^{[28]}$ Treatment did not create significant difference between phytotherapuetic combination and placebo group in clinical improvement. Use of phytotherapeutic agents in the treatment of BPH yielded clinical and urodynamic effects comparable to placebo. ${ }^{[28]}$

Limitations of our study include inability to examine effects of I/R on contralateral testes. Furthermore, we didn't analyze antiapoptotic effect using TUNEL assay as did studies cited in the literature.

\section{Conclusion}

In conclusion, it has been demonstrated that I/R lasting for 5 hours causes significant testicular injury. Application of UD improved biochemical and histopathological parameters of $I / R$ testis. To the best of our knowledge, ours is the second experimental study performed to demonstrate impact of UD on I/R induced testicular injury. In clinical settings, we think that use of UD may be a promising approach in the management of testicular torsion. However, further investigations should be conducted on mice to determine potential effects of UD on testicular torsion/ detorsion-induced I/R injury.

Authorship contributions

Concept: H.A.; Design: H.A.; Data collection \&/or processing: H.A.; Analysis and/or interpretation: H.A.; Literature search: H.A.; Writing: H.A.; Critical review: H.A.

Conflict of interest

None declared.

\section{REFERENCES}

1. Williamson RC. The continuing conundrum of testicular torsion. $\mathrm{Br}$ J Surg 1985;72:509-10. [CrossRef]

2. Lysiak JJ, Nguyen QA, Turner TT. Peptide and nonpeptide reactive oxygen scavengers provide partial rescue of the testis after torsion. $\mathrm{J}$ Androl 2002;23:400-9.

3. Aksu Mİ, Kaya M. The effect of $\alpha$-tocopherol and butylated hydroxyanisole on the colour properties and lipid oxidation of kavurma, a cooked meat product. Meat Sci 2005;71:277-83. [CrossRef]

4. Di Lorenzo C, Dell'Agli M, Badea M, Dima L, Colombo E, Sangiovanni E, et al. Plant food supplements with anti-inflammatory properties: a systematic review (II). Crit Rev Food Sci Nutr 2013;53:507-16.

5. Kataki MS, Murugamani V, Rajkumari A, Mehra PS, Awasthi D, Yadav RS. Antioxidant, Hepatoprotective, and Anthelmintic Activities of Methanol Extract of Urtica dioica L. Leaves. Pharmaceutical Crops 2012;3:38-46. [CrossRef]

6. Fattahi S, Ardekani AM, Zabihi E, Abedian Z, Mostafazadeh A, Pourbagher R, et al. Antioxidant and apoptotic effects of an aqueous extract of Urtica dioica on the MCF-7 human breast cancer cell line. Asian Pac J Cancer Prev 2013;14:5317-23. [CrossRef]

7. Ghorbanibirgani A, Khalili A, Zamani L. The efficacy of stinging nettle (urtica dioica) in patients with benign prostatic hyperplasia: a randomized double-blind study in 100 patients. Iran Red Crescent Med J 2013;15:9-10. [CrossRef]

8. Sayhan MB, Kanter M, Oguz S, Erboga M. Protective effect of Urtica dioica L. on renal ischemia/reperfusion injury in rat. J Mol Histol 2012;43:691-8. [CrossRef]

9. Oguz S, Kanter M, Erboga M, Ibis C. Protective effect of Urtica dioica on liver damage induced by biliary obstruction in rats. Toxicol Ind Health 2013;29:838-45. [CrossRef]

10. Unsal A, Eroglu M, Avci A, Cimentepe E, Guven C, Derya Balbay $\mathrm{M}$, et al. Protective role of natural antioxidant supplementation on testicular tissue after testicular torsion and detorsion. Scand J Urol Nephrol 2006;40:17-22. [CrossRef]

11. Ozbal S, Ergur BU, Erbil G, Tekmen I, Bagriyanık A, Cavdar Z. The 
effects of $\alpha$-lipoic acid against testicular ischemia-reperfusion injury in Rats. Scientific World Journal 2012;2012:489248. [CrossRef]

12. Johnsen SG. Testicular biopsy score count-a method for registration of spermatogenesis in human testes: normal values and results in 335 hypogonadal males. Hormones 1970;1:2-25. [CrossRef]

13. Cosentino MJ, Nishida M, Rabinowitz R, Cockett AT. Histopathology of prepubertal rat testes subjected to various durations of spermatic cord torsion. J Androl 1986;7: 23-31. [CrossRef]

14. Zimmerman BJ, Granger DN. Reperfusion injury. Surg Clin North Am 1992;72:65-83. [CrossRef]

15. Shimizu S, Saito M, Dimitriadis F, Kinoshita Y, Shomori K, Satoh $\mathrm{I}$, et al. Protective effect of ischaemic post-conditioning on ipsilateral and contralateral testes after unilateral testicular ischaemia-reperfusion injury. Int J Androl 2011;34:268-75. [CrossRef]

16. Harrison RG, Lewis-Jones DI, Moreno de Marval MJ, Connolly RC. Mechanism of damage to the contralateral testis in rats with an ischaemic testis. Lancet 1981;2:723-5. [CrossRef]

17. Shiraishi K, Naito K, Yoshida K. Nitric oxide promotes germ cell necrosis in the delayed phase after experimental testicular torsion of rat. Biol Reprod 2001;65:514-21. [CrossRef]

18. Lewis-Jones DI, Moreno de Marval M, Harrison RG. Impairment of rat spermatogenesis following unilateral experimental ischemia. Fertil Steril 1982;38:482-90. [CrossRef]

19. Sarica K, Küpeli B, Budak M, Koşar A, Kavukçu M, Durak I, et al. Influence of experimental spermatic cord torsion on the contralateral testis in rats. Evaluation of tissue free oxygen radical scavenger enzyme levels. Urol Int 1997;58:208-12. [CrossRef]

20. Madgar I, Lunenfeld B, Mashiach S, Goldwasser B, Weissenberg R. Effect of testicular torsion on contralateral testis and fertility in mature rats. Arch Androl 1987;19:237-41. [CrossRef]

21. Oguz S, Kanter M, Erboga M, Toydemir T, Sayhan MB, Onur H. Effects of Urtica dioica on oxidative stress, proliferation and apoptosis after partial hepatectomy in rats. Toxicol Ind Health 2015;31:475-84.

22. Ghafari S, Balajadeh BK, Golalipour MJ. Effect of Urtica dioica L. (Urticaceae) on testicular tissue in STZ-induced diabetic rats. Pak J Biol Sci 2011;14:798-804. [CrossRef]

23. Golalipour MJ, Kabiri Balajadeh B, Ghafari S, Azarhosh R, Khori V. Protective Effect of Urtica dioica L. (Urticaceae) on Morphometric and Morphologic Alterations of Seminiferous Tubules in STZ Diabetic Rats. Iran J Basic Med Sci 2011;14:472-7.

24. Kanter M, Meral I, Dede S, Gunduz H, Cemek M, Ozbek H, et al. Effects of Nigella sativa L. and Urtica dioica L. on lipid peroxidation, antioxidant enzyme systems and some liver enzymes in CCl4-treated rats. J Vet Med A Physiol Pathol Clin Med 2003;50:264-8. [CrossRef]

25. Cai T, Mazzoli S, Bechi A, Addonisio P, Mondaini N, Pagliai RC, et al. Serenoa repens associated with Urtica dioica (ProstaMEV) and curcumin and quercitin (FlogMEV) extracts are able to improve the efficacy of prulifloxacin in bacterial prostatitis patients: results from a prospective randomised study. Int J Antimicrob Agents 2009;33:549-53. [CrossRef]

26. Safarinejad MR. Urtica dioica for treatment of benign prostatic hyperplasia: a prospective, randomized, double-blind, placebo-controlled, crossover study. J Herb Pharmacother 2005;5:1-11. [CrossRef]

27. Lopatkin N, Sivkov A, Schläfke S, Funk P, Medvedev A, Engelmann U. Efficacy and safety of a combination of Sabal and Urtica extract in lower urinary tract symptoms-long-term follow-up of a placebo-controlled, double-blind, multicenter trial. Int Urol Nephrol 2007;39:1137-46. [CrossRef]

28. Melo EA, Bertero EB, Rios LA, Mattos D Jr. Evaluating the efficiency of a combination of Pygeum africanum and stinging nettle (Urtica dioica) extracts in treating benign prostatic hyperplasia $(\mathrm{BPH})$ : double-blind, randomized, placebo controlled trial. Int Braz J Urol 2002;28:418-25.

\section{Sıçan Modelinde Testiküler Torsiyon/Detorsiyona Bağıı Gelişen İskemi Reperfüzyonun Hasarında Urtica Dioica'nın Koruyucu Rolü}

Amaç: Bu çalışmada, Urtica Dioica'nın (UD) torsiyon/detorsiyon kaynaklı testiküler I/R yaralanması üzerindeki potansiyel koruyucu rolünün araştırılması amaçlandı.

Gereç ve Yöntem: Toplamda 32 adet erkek Wistar albino cinsi sıçan (her bir grupta sekiz hayvan) dört gruba ayrıldı: Grup I Sham: Opere edilen kontrol grubu, Grup 2: I/R yapılan grup, Grup 3: UD verilen grup ( 14 gün süreyle $250 \mathrm{mg} / \mathrm{kg}$ ), Grup 4: I/R+UD grubu. Sağ testis saat yönünde $720^{\circ}$ döndürülerek torsiyon oluşturuldu. İskemi süresi beş saat idi ve orşiektomi detorsiyon sonrası beşinci saate yapıldı.

Bulgular: Testiküler dokuların biyokimyasal analizinde, MDA i/R grubunda kontrol ve UD grubuna kıyasla anlamlı olarak yüksekti. Aynı anlamlı yükseklik I/R+UD grubu kontrol ve UD grubuyla kıyaslandığında da tespit edildi. Ancak testiküler doku GSH seviyeleri gruplar arasında anlamlı fark oluşturmadığı gözlendi. Ek olarak UD tedavisi alan hayvanlar İ/R grubuyla karşılaştırıldığında daha iyi histopatolojik bulgular göstermiştir.

Sonuç: Günümüzde, testiküler torsiyon/detorsiyon sonrası gelişen İ/R hasarında UD tedavisi sonrası histopatolojik değişiklikleri inceleyen çok nadir çalışma mevcuttur. Urtica Dioica ileride testiküler torsiyonun tedavisinde gelecek vaat eden bir yaklaşım olabileceği düşünülmektedir.

Anahtar Sözcükler: İskemi-reperfüzyon; orşiektomi; testiküler torsiyon/detorsiyon; Urtica Dioica. 